\title{
Ankaferd blood stopper: A novel hemostatic agent with unique antimicrobial, antineoplastic and regenerative properties
}

\author{
Aditi CHOPRA $1 *$ (D), Karthik SIVARAMAN 2 (D) \\ 1 Department of Periodontology, Manipal College of Dental Sciences, Manipal Academy of Higher Education, \\ Manipal, Karnataka, India. \\ 2 Department of Prosthodontics, Manipal College of Dental Sciences, Manipal Academy of Higher Education, \\ Manipal, Karnataka, India. \\ * Corresponding Author: E-mail: draditichopra@gmail.com (A.C.); Tel. +91-0820-292 2173.
}

Received: 05 December 2018/ Revised: 01 June 2019 / Accepted: 02 June 2019

\begin{abstract}
A folkloric herbal extract of five plants (Thymus vulgaris, Glycyrrhiza glabra, Vitis vinifera, Alpinia officinarum, and Urtica dioica), is emerging as a promising hemostatic agent with strong immunological, antiinflammatory, antimicrobial, anti-mutagenic, and antioxidant properties. Though its use as a hemostatic agent in the various general surgical procedure involving gastrointestinal, variceal, presacral bleeding, burns, and epistaxis, etc. is established, very little data comprehensively highlights the mechanisms and clinical application of this potential folkloric combination. The present paper aims to highlight the mechanism of this unique herbal combination with the aim to lay the foundation for further research using this novel hemostatic agent.
\end{abstract}

KEYWORDS: Ankaferd blood stopper; antibiotic resistance; antimicrobial; plant extracts, herbal medicines; hemostatic.

\section{INTRODUCTION}

A unique herbal folkloric Turkish medicinal extract prepared from five different plants: (Thymus vulgaris (dried grass extract) $(5.0 \mathrm{~g} / 100 \mathrm{ml})$, Glycyrrhiza glabra (dried leaf extract) $(7.0 \mathrm{~g} / 100 \mathrm{ml})$, Vitis vinifera (dried leaf extract) $(8.0 \mathrm{~g} / 100 \mathrm{ml})$, Alpinia officinarum (dried leaf extract) $(7.0 \mathrm{~g} / 100 \mathrm{ml})$, and Urtica dioica (dried root extract) $(6.0 \mathrm{~g} / 100 \mathrm{ml})$, has shown to possess promising hemostatic, regenerative, anti-neoplastic and antimicrobial properties against multidrug-resistant bacteria. It is commonly available as a tampon, spray, and ampules under the trade name of Ankaferd Blood Stopper (ABS), (Ankaferd Ilac Kozmetik AS, Istanbul, Turkey) [1-3]. ABS is a unique hemostatic agent used to control post-operative hemorrhage in patients with various bleeding disorders. Apart from providing good hemostasis, it is also known to promote cytokineinduced neovascularization that helps in rapid wound healing and treatment of neoplasms[3-9]. The paper aims to describe the unique and intricate mechanisms and highlight the evidence that supports the use of this novel hemostatic agent. The paper also aims to lay the foundation and acts as the keystone for initiating further research in this aspect.

\section{MECHANISMS OF ACTION}

\subsection{Hemostatic properties}

ABS is approved as a hemostatic agent in Turkey for managing a postoperative hemorrhage, especially with patients with hereditary or acquired hemorrhagic diathesis. A phase I, double-blind, randomized crossover placebo-controlled clinical study confirmed the safety and efficacy of this unique hemostatic agent for the management of external hemorrhage in various general and oral surgical procedures [7]. It has proved to be an effective hemostatic agent to control bleeding after gastrointestinal and urologic surgery, Transradial Coronary Angiography, tonsillectomy, acute anterior epistaxis, etc.[8-17].

How to cite this article: Chopra A, Sivaraman K. Ankaferd blood stopper: a novel hemostatic agent with unique antimicrobial, antineoplastic and regenerative properties. J Res Pharm. 2019; 23(5): 777-784. 
Various Phase III clinical trials in humans, that used ABS to control vascular port insertion bleedings, anterior epistaxis, and post-tonsillectomy hemorrhages, confirmed that ABS can control bleeding effectively during the surgical procedure [5,6,16,17]. Teker et al. (2009) also compared and evaluated the use of this herbal combination in patients undergoing cryogenic tonsillectomy at the tonsillar bed to the suture ligation technique and confirmed that the hemostasis achieved with ABS was faster as compared to the sutured site $[16,17]$. ABS is also regarded as a more superior agent in controlling the gastrointestinal and nose bleeding compared to the conventional methods of hemostasis [9]. ABS is superior to Surgicel in controlling bleeding from a laceration of the liver. Studies have also confirmed that livers treated with ABS complete their regeneration with minimal signs of inflammation and improved intra-abdominal adhesion scores [18]. ABS is also a good hemostatic agent for controlling bleeding during and after various oral and periodontal surgeries [15-19].

Another advantage of ABS compared to other hemostatic agent is its ability to form the clot in less than one second and to anchor the physiologically aggregated erythrocytes. ABS is also known to stimulate the endothelial cells and other individual components of blood to promote cell proliferation. Various chemical mediators are also released upon 'ABS web' formation [19-22]. The electron microscopy, light microscopy, and histopathology sections of the clotted tissues after ABS application have revealed the formation 'ABS web.' is an erythroid-rich aggregate within the encapsulated protein network. The 'ABS web' provides focal points for vital erythrocyte aggregation and acts like a magnet to attract erythrocytes $[19,20]$. ABS influence the entire physiological hemostatic mechanism by interacting with blood proteins, particularly with fibrinogen gamma and prothrombin and forming a unique protein network. Another unique property of ABS is that the hemostasis is achieved via the classical cascade model of the clotting system without affecting the coagulation cascade and platelet function. The coagulation factors like factors II, V, VII, VIII, IX, XI, and XII are not affected by ABS [2]. However, the levels of albumin and globulin are decreased upon addition to ABS [2,4,6].

Additionally, it has been observed that proteins present in the protein library of ABS interact with the ankyrin and spectrin receptors on the surface of red blood cells. This aid in the stabilization, vital erythroid aggregation, and clot formation. Essential erythroid proteins in the protein library of ABS include (ankyrin recurrent and FYVE bundle containing protein 1, spectrin alpha, actin-depolymerization factor, actindepolymerizing factor, LIM bundle and actin binding subunit 1 isoform a, NADH dehydrogenase [ubiquinone] 1 alpha, mitochondrial NADP [+] dependent malic enzyme 3, ribulose bisphosphate carboxylase large chain [maturase K]). Along with these molecules, various ATP bioenergy molecules like ATP synthase, ATP synthase beta subunit, ATP synthase alpha subunit, ATP binding protein C12, TP synthase H+ transporter protein, ADF, alpha-1, 2-glycosyltransferase ALG10-A]) are also used to achieve hemostasis. ABS also up-regulates the GATA (FOG) transcription system that affects the erythroid function and aid in the formation of urotensin II. Urotensin II acts as a link between the injured vascular endothelium, adhesive proteins, and active erythroid cells [21-24].

However, the efficacy of ABS depends upon the direct contact of the hemostatic agent with the bleeding surface. Since a dirty-white colored hemostatic web, the detection of the bleeding lesions becomes difficult. Therefore, the hemostatic agent should be applied after precisely locating the source of the oozing blood [1923]. Since, the protein network covering the bleeding site's forms without altering the physiological hemostatic process and clotting factor, it can be effectively used in patients with hereditary or acquired hemorrhagic diathesis such as afibrinogenemia, Hemophilia, Von Willebrand disease, hereditary thrombocytopenia, Glanzmann thrombasthenia, patients taking antithrombotic, procoagulant, and antifibrinolytic medications [23-34].

Various animal studies have confirmed that ABS can shorten both the duration and the amount of bleeding. Al et al. (2009) investigated and compared the efficacy of ABS to control cutaneous and subcutaneous hemorrhages during vascular access in malignancy with ABS absorbed tampon at the bleeding sites with subjects who received a dry gauze tampon. The study concluded that the bleeding stopped at 32.97 seconds in the ABS group, and 123.75 seconds in the dry gauze tampon group [21]. Cipil et al. (2009) evaluated the hemostatic effect of ABS in rats pretreated with warfarin $(2 \mathrm{mg} / \mathrm{kg})$ and compared it to $0.9 \%$ sodium chloride after a bilateral hind leg amputation [25]. The result concluded that topical administration of this herbal blend to the amputated leg markedly shortened the duration of bleeding in warfarin-treated and untreated rats. Furthermore, the amount of bleeding from the amputated leg was reduced by $50 \%$ in the ABS group as compared to the warfarin-treated group. Kosar et al. (2009), studied the efficacy of ABS in controlling bleeding in animals pretreated with acetylsalicylic acid or enoxaparin sodium as compared to another anticoagulant and confirmed that topical application of ABS reduced both the duration and the amount of bleeding [31]. 
Oner et al. (2010) assessed the difference in the amount of hemostasis with Factor VIII inhibitor, cyclophosphamide, prednisolone, and ABS in a pediatric hemophiliac and reported that ABS is more effective than commonly used hemostatic agent to control bleeding in the hemophilic patient [32,33]. ABS is also found to be more effective than adrenaline plus lidocaine and gelatin foam in the controlling epistaxis. Topical nasal ABS application is better than cotton, gelatin foam, and adrenaline with lidocaine to control epistaxis [28].

This hemostatic properties of ABS can be utilized for controlling bleeding during various oral, periodontal and implant-related surgical procedures such as deep subgingival scaling and root planing, gingivectomy, frenotomy, frenectomy, vestibuloplasty, open flap debridement, free gingival graft, soft tissue connective graft, ridge augmentation, etc. Baykul et al. (2010) investigated the effect of using ABS in patients undergoing different dental procedures and concluded that ABS can effectively control the bleeding within 10-20 minutes [4] [29]. Kazancioglu HO et al. (2013), in a randomized controlled clinical trial, assessed the hemostatic efficacy of ABS in controlling bleeding following tooth extraction [29]. The result confirmed that ABS is more superior to other local hemostatic agents like gauze and suture to control bleeding in hemophilic patients. Additionally, there is no need to reduce the dosage or stop the oral anticoagulant therapy in patients with any bleeding disorder before undergoing routine dental treatment, if ABS is used.[29] Thus, ABS can be used successfully in patients undergoing antithrombotic treatment with acetylsalicylic acid and warfarin sodium without interrupting and/or altering the anticoagulant regimens [30]. Trakyali G and Oztoprak MO (2010) is also beneficial effects of using ABS while placing orthodontic brackets on surgically exposed impacted or partially erupted teeth [38-40]. ABS can effectively control the gingival bleeding and prevent contamination during orthodontic bracket placement. This can also enhance the shear bond strength and longevity of the placed orthodontic brackets $[39,40]$. ABS is even proposed as an alternative to formacresol and Ferric Sulphate for pulpotomy in primary teeth [41-45]. Koyuturk et al. (2013) histologically compared the use of ABS to formacresol and ferric sulphate as a pulpotomy agent and showed that although there was no significant difference in the inflammatory response between ABS and ferric sulphate, high inflammatory cells are observed with formacresol [44]. Moreover, unlike ABS, ferric sulfate interacts with the components of the blood and occlude the capillary orifices of the pulp to prevent bleeding. Thus, ABS is considered as a superior alternative to ferric sulphate and formacresol for pulpotomy in primary molars. Odabas et al. (2011) also evaluated the prognosis of calcium hydroxide pulpotomy with and without ABS application and concluded a 90\% and 95\% success rate with calcium hydroxide and Calcium hydroxide + ABS group respectively [41-44].

\subsection{Antimicrobial properties}

This unique herbal combination is known to possess powerful antimicrobial properties against multidrug resistant bacteria [5-8,12-14]. The antimicrobial property helps to control the postoperative infections after various oral and periodontal surgical procedures where chances of contamination with potent facultative anaerobic bacteria are high [7-10]. Another advantage of ABS is its ability to enhance the healing and control of post-operative infection in immune-compromised and geriatric patients where the chances of postoperative infection are high. Fisgin et al. (2009) evaluated the robust antimicrobial efficacy of ABS against various multi-resistant Gram-positive and Gram-negative bacteria, such as Vancomycin-Resistant Enterococcus(VRE), methicillin-resistant Staphylococcus aureus (MRSA), Escherichia coli, Acinetobacter baumannii, Klebsiella pneumonia, Pseudomonas aeruginosa, Enterobacter species, Stenotrophomonas maltophilia [7-11]. Cinar et al. (2012) also proved the antibacterial efficacy of ABS on various oral and periodontal pathogens. ABS is found to be effective against Staphylococcus aureus, Streptococcus pyogenes, Streptococcus mutans, Staphylococcus epidermidis, Candida albicans, Porphyromonas gingivalis, Lactobacillus acidophilus, Lactobacillus salivarius, Aggregatibacter actinomycetemcomitans [9].

The strong antimicrobial potential is due to the release of an array of proteins like NADP-dependent malic enzyme, ribulose biphosphatecarbocsilase, maturase K, ATP synthase beta subunit, ATP synthase alpha subunit, chalcone flavon isomerase $1 \& 2$, and actin depolymerization factor. The release of this diverse array of proteins up-regulates the release of various critical transcription factors that affect the pathobiology of various infectious diseases. ABS can even inhibit lipopolysaccharide-induced endotoxemia by enzymatic activation of Protease-Activated Receptor-1 (PAR-1), Endothelial Protein C Receptor (EPCR) and Plasminogen Activator Inhibitor-1 (PAI-1) [20-24,35]. However, the mechanisms of action of ABS in treating nosocomial and drug-resistant infections remain unclear and needs further research and investigations. ABS is also known to inhibit the growth of various yeast and filamentous fungi. Ciftci et al. (2011) assessed the antifungal effect of ABS using a good diffusion agar test and found that ABS has a high antifungal effect against Zygosaccharomyces bailii, Candida albicans, Aspergillus flavus, and Aspergillus parasiticus [47]. Pellati et al. (2009) and Motsei et al. (2003) also demonstrated that 18-beta glycyrrhetinic acid, the key components of ABS, is known to possess a 
strong antifungal effect on the Candida albicans [36,37]. This property can be utilized for preparing various antifungal mouthwashes for the treatment of oral candidiasis and other fungal infections [47-52]. Therefore ABS should be tried as an antiplaque and anti-gingivitis agent for the treatment of gingivitis, periodontitis, periapical, periodontal abscess and postoperative infections following periodontal surgery. However long term longitudinal and comparative randomized clinical trials are required to confirm the antimicrobial efficacy of this unique herbal hemostatic agent. Moreover, in this dooming era of antibiotic resistance, there is an urgent need to explore the antimicrobial property of this unique herbal combination and develop novel therapeutic tools in treating infectious diseases due to multidrug-resistant bacteria.

\subsection{Regenerative and anti-apoptotic properties}

ABS is known to enhance hard and soft tissues healing as it also increases the tissue oxygenation along with superior regenerative, antioxidant and pro-angiogenic properties [46,47-49]. Moreover, ABS can be considered as a better option in inducing regenerating epithelium than epinephrine. The intravesical administration of ABS is as efficacious as epinephrine in terms of congestion, edema, necrosis, and ulceration. This properties of ABS can be utilized in the treatment of periodontitis-induced osseous defects, periodontal plastic surgery for root coverage, aesthetic surgery for papilla regeneration and healing of orofacial burns [46-49,54]. Bulut E et al. (2014) analyzed and compared the effects of ABS and routine antibiotic prophylaxis on early healing of periodontal osseous defects in diabetic rats and non-diabetic rats by histopathology and stereological examination [50]. The results showed that local administration of ABS significantly increased the mean volume of the newly formed bone in both diabetic and non-diabetic rats at 7 and 14 days. No significant difference in new bone formation was observed between ABS and antibiotic group in the diabetic rats. The osseous defects treated with ABS have a more intense bone formation with less occurrence of necrosis, fibrosis, and foreign body reaction. ABS also accelerates bone healing with rapid bone formation by inhibiting the action of proinflammatory cytokines such as Prostaglandin E2, Thromboxane B2, and Leukotriene B4 [46]. Thus it was concluded that antibiotic prophylaxis and ABS have beneficial effects on the healing of bone in diabetic animals [52].

Pamuk et al. (2016) compared the clinical efficacy and expression of Vascular Endothelial-derived Growth Factor (VEGF) upon the use of ABS in combination with autogenous cortical bone graft for the treatment periodontitis induced intra-osseous defects [51]. There was a significant increase in the VEGF concentration when ABS was used along with bone graft as compared to bone graft alone. The VEGF enhance regeneration of periodontal tissues along with improved wound healing, angiogenesis and reduced gingival inflammation at the defect site $[45,47,48,52-55]$. The ABS induced release of VEGF also increases the regenerative potential of the bone graft and promotes superior soft tissue healing, clinical attachment gain and reduce the incidence of post-operative gingival recession. Moreover, ABS is considered as a better biological scaffold for bone graft due to its dense and resistant nature. However, its space-maintaining ability in periodontal defects is not ideal due to its non-rigid feature. Therefore, ABS should be used with a bone graft material that that is more stable and maintain space until regeneration is completed.

\subsection{Anticancer and anti-apoptotic effects}

The anti-neoplastic and anti-apoptotic property of ABS was first studied on Sarcoma osteogenic (Saos2), an osteosarcoma cell line by Goker et al in 2008 [54,55]. Various concentration of ABS solution $(2,4,6,8$, and $10 \mu \mathrm{L} / \mathrm{mL}$ ) was used to analyze the growth and proliferation of the Saos 2 cells. The result showed a dosedependent suppression in the proliferation and survival of the Saos 2 cell culture. The aggregation of the cells in the cell culture was amplified when higher doses of ABS was used. A dose-dependent suppression of the cell with loss of cell adhesion between the Saos-2 osteosarcoma cells has been observed with ABS [56,57]. Based on these observations, the antineoplastic properties of ABS in treating colon cancer was evaluated. ABS was found to be an effective agent in controlling the cellular mitosis of human colon cancer cells in vitro in a dosedependent manner. It was also observed that the cancerous cells when exposed to ABS lose their adhesiveness and viability. The suppressor effect of ABS on colon cancer cells was detected at $2 \mu \mathrm{L} / \mathrm{mL}$ level and became more prominent at $10 \mu \mathrm{L} / \mathrm{mL}$ concentration. ABS was also found to induce apoptosis, regulate cellular proliferation, and decrease tumor vascularization [58]. This anti-neoplastic activities of ABS have been utilized for treating leukemia and lymphoid neoplastic cell lines have also been observed [57,58]. Mumcuoglu et al. (2015) evaluated the anti-cancer efficacy of ABS on leukemia cells and observed that the expression of PAR1 and EPCR depends on the dosage of ABS on Jurkat cells and K562 cells. Furthermore, ABS is known to trigger apoptosis of the leukemic cells $[57,58]$. The antineoplastic effects of ABS on leukemic cells is observed at higher doses $(>0.5 \mu \mathrm{g} / \mathrm{mL})$. At lower doses $(<0.5 \mu \mathrm{g} / \mathrm{mL})$ ABS can induce cellular differentiation. ABS is known to 
apoptosis by regulating PAR1 and p53-independent p21 involvement in apoptosis stimulation in leukemia cells [58]. Akalin et al. (2009) also proved ABS (dosage: $0.5,1$, and $2 \mu \mathrm{g} / \mathrm{mL}$ ) can prevent the transformation of the B cell chronic lymphocytic leukemia cells into aggressive blastic lymphocytes. It can also kill almost $50 \%$ of the cells and prevents the inflammation induced by B cell chronic lymphocytic leukemia cells [57].

The anti-tumor and anti-apoptotic properties of ABS is due to its ability to up-regulate the level of diverse types of proteins and factors acting on cellular functions. ABS is known to activate receptors like androgen receptor, cyclic AMP response element or activating transcription factor-1 (CRE-ATF1), cyclic AMP binding protein, interferon-stimulated response element, Nuclear Factor-1(NF-1), protein-53 (p53), Peroxisome Proliferator-Activated Receptor (PPAR) and Yin-Yang (YY1). It also alters the proteinase-activated receptor 1 (PAR1) and endothelial protein C receptor (EPCR) expression in K562 and Jurkat cells in a time and dose-dependent manner [24]. The addition of ABS to the synovial fluid also demonstrates a rapid frozen gellike solidification. ABS interacts with the synovial fluids and induce a decrease in the levels of protein and promote the aggregation of both the protein components as well as the high molecular weight saccharide-rich hyaluronic acid in synovial fluid. This observation along with the good hemostatic and wound healing properties makes ABS a novel and promising an intra-articular agent for the management of hemarthrosis, especially in patients with defective hemostasis. These factors play an important role in regulating various cellular mechanisms, such as signal transduction, mitosis, apoptosis, angiogenesis, cell cycle regulation, immunologic processes and metabolic pathways [1]. These properties of ABS can be utilized to treat various cancerous lesion such as leukemia, osteosarcoma, synovial joint disorder. These novel findings open a fertile area of further research to develop novel therapeutic modalities to treat leukemia.

\section{CONCLUSION}

ABS is a promising hemostatic agent with good antimicrobial, regenerative and reparative potential. However, long-term randomized clinical trials comparing the efficacy of ABS with already established hemostatic and antimicrobial agents are warranted. Further research to evaluate the clinical efficacy of this novel folkloric herbal combination in managing multi-drug resistant infection, osseous regeneration and wound healing is required to develop novel therapeutic modalities.

Author contributions: Concept - A.C., K.S.; Design - A.C., K.S.; Supervision - A.C. K.S.; Materials - A.C., K.S.; Data Collection and/or Processing - A.C., K.S.; Analysis and/or Interpretation - A.C., K.S.; Literature Search - A.C., K.S.,Writing - A.C., K.S.; Critical Reviews A.C., K.S.

Conflict of interest statement: The authors declared no conflict of interest.

\section{REFERENCES}

[1] Chen C, Yang FQ, Zhang Q, Wang FQ, Hu YJ, Xia ZN. Natural Products for Antithrombosis. Evid Based Complement Alternat Med. 2015; 2015: 876426. [CrossRef]

[2] Goker H, Haznedaroglu IC, Ercetin S, Kirazli S, Akman U, Ozturk Y, Firat HC. Hemostatic actions of the folkloric medical plant extract Ankaferd Blood Stopper. J Int Med Res. 2008; 36: 163-170. [CrossRef]

[3] Beyazit Y, Kurt M, Kekilli M, Goker H, Haznedaroglu IC. Evaluation of hemostatic effects of Ankaferd as an alternative medicine. Altern Med Rev. 2010; 15: 329-336.

[4] Baykul T, Alanoglu EG, Kocer G. Use of Ankaferd Blood Stopper as a hemostatic agent: A clinical experience. J Contemp Dent Pract. 2010; 11(1): E088-E094.

[5] Aktas A, Nuray ER, Kırıs S, Koseoglu OT, Haznedaroglu IC. The efficiency of Ankaferd Blood Stopper during the dental surgery in hemorrhagic. Diathesis: Case Series. Int J Hematol Oncol. 2010; 20: 1-5. [CrossRef]

[6] Balcik OS, Koroglu M, Cipil H, Kaftan O, Maral S, Gurel A, et al. A placebo controlled, randomized, double-blinded, cross-over phase 1 clinical study to demonstrate safety of Ankaferd Blood Stopper topical usage in healthy volunteers. Int J Lab Hem. 2010; 32: 126-127. [CrossRef]

[7] Bilgili H, Captug O, Kosar A, Kurt M, Kekilli M, Shorbagi A, Kurt OK, Ozdemir O, Goker H, Haznedaroglu IC. Oral systemic administration of Ankaferd blood stopper has no short-term toxicity in an in vivo rabbit experimental model. Clin Appl Thromb Hemost. 2010; 16(5): 533-536. [CrossRef] 
[8] Tasdelen Fisgin N, Tanriverdi Cayci Y, Coban AY, Ozatli D, Tanyel E, Durupinar B, Tulek N. Antimicrobial activity of plant extract Ankaferd Blood Stopper. Fitoterapia. 2009; 80(1): 48-50. [CrossRef]

[9] Cinar C, Odabas ME, Akca G, Isik B. Antibacterial effect of a new hemostatic agent on oral microorganisms. J Clin Exp Dent. 2012; 4(3): e151-e155. [CrossRef]

[10] Aysan E, Bektas H, Ersoz F, Sari S, Kaygusuz A, Huq GE. Ability of the Ankaferd Blood Stopper ${ }^{\circledR}$ to prevent parenchymal bleeding in an experimental hepatic trauma model. Int J Clin Exp Med 2010; 3: 186-190.

[11] Huri E, Haznedaroglu IC, Akgul T, Astarci M, Ustun H, Germiyanoulu C. Biphasic effects of Ankaferd blood stopper on renal tubular apoptosis in the rat partial nephrectomy model representing distinct levels of hemorrhage. Saudi Med J. 2010; 30: 864-868.

[12] Kurt M, Kacar S, Onal IK, Akdogan M, Haznedaroglu IC. Ankaferd Blood Stopper as an effective adjunctive hemostatic agent for the management of life-threatening arterial bleeding of the digestive tract. Endoscopy. 2008; 40(2): E262. [CrossRef]

[13] Kurt M, Akdogan M, Onal IK, Kekilli M, Arhan M, Shorbagi A, Aksu S, Kurt OK, Haznedaroglu IC. Endoscopic topical application of Ankaferd Blood Stopper for neoplastic gastrointestinal bleeding: a retrospective analysis. Dig Liver Dis. 2010; 42(3): 196-199 [CrossRef]

[14] Kurt M, Onal I, Akdogan M, Kekilli M, Arhan M, Sayilir A, Oztas E, Haznedaroglu I. Ankaferd Blood Stopper for controlling gastrointestinal bleeding due to distinct benign lesions refractory to conventional antihemorrhagic measures. Can J Gastroenterol. 2010; 24: 380-384. [CrossRef]

[15] Ozaslan E, Purnak T, Yildiz A, Haznedaroglu IC. A new candidate as a hemostatic agent for difficult situations during variceal bleeding: Ankaferd blood stopper. Saudi J Gastroenterol. 2011; 17(2): 145-148. [CrossRef]

[16] Teker AM, Korkut AY, Gedikli O, Kahya V. Prospective, controlled clinical trial of Ankaferd Blood Stopper in children undergoing tonsillectomy. Int J Pediatr Otorhinolaryngol. 2009; 73(12): 1742-1745. [CrossRef]

[17] Teker AM, Korkut AY, Kahya V, Gedikli O. Prospective, randomized, controlled clinical trial of Ankaferd Blood Stopper in patients with acute anterior epistaxis. Eur Arch Otorhinolaryngol. 2010; 267: 1377-1381. [CrossRef]

[18] Karakaya K, Ucan HB, Tascilar O, Emre AU, Cakmak GK, Irkorucu O, Ankarali H, Comert M. Evaluation of a new hemostatic agent Ankaferd Blood Stopper in experimental liver laceration. J Invest Surg. 2009; 22(3): $201-206$. [CrossRef]

[19] Haznedaroglu IC. Molecular basis of the pleiotropic effects of Ankaferd Blood Stopper. IUBMB Life. 2009; 61(3): 290.

[20] Haznedaroglu BZ1, Beyazit Y, Walker SL, Haznedaroglu IC. Pleiotropic cellular, hemostatic, and biological actions of Ankaferd hemostat. Crit Rev Onco Hematol. 2012; 83(1): 21-34. [CrossRef]

[21] Al B, Yildirim C, Cavdar M, Zengin S, Buyukaslan H, Kalender ME. Effectiveness of Ankaferd blood stopper in the topical control of active bleeding due to cutaneous-subcutaneous incisions. Saudi Med J. 2009; 30(12): 1520-1525.

[22] Akar N, Demiralp DO, Haznedaroglu IC, Goker H. Functional Proteomics of Ankaferd Blood Stopper. Blood. 2008; 112: 4103.

[23] Haznedaroglu BZ, Haznedaroglu IC, Walker SL, Bilgili H, Goker H, Kosar A. Ultrastructural and morphological analyses of the in vitro and in vivo hemostatic effects of Ankaferd Blood Stopper. Clin Appl Thromb Hemost. 2010; 16(4): 446-453. [CrossRef]

[24] Yilmaz E, Gulec S, Haznedaroglu IC, Akar N. Effects of Ankaferd on HUVEC transcription factors and erythrocyte protein profile. Turk J Hematol. 2011; 28(4): 276-285. [CrossRef]

[25] Cipil HS, Kosar A, Kaya A, Uz B, Haznedaroglu IC, Goker H, et al. In vivo hemostatic effect of the medicinal plant extract Ankaferd Blood Stopper in rats pretreated with warfarin. Clin Appl Thromb Hemost. 2009; 15(3): $270-276$. [CrossRef]

[26] Kurt M, Disibeyaz S, Akdogan M, Sasmaz N, Aksu S, Haznedaroglu IC. Endoscopic application of ankaferd blood stopper as a novel experimental treatment modality for upper gastrointestinal bleeding: A case report. Am J Gastroenterol. 2008; 103(8): 2156-2158.

[27] Ibis M, Kurt M, Onal IK, Haznedaroglu IC. Successful management of bleeding due to solitary rectal ulcer via topical application of Ankaferd blood stopper. J Altern Complement Med. 2008; 14(9): 1073-1074. [CrossRef]

[28] Kelles M, Kalcioglu MT, Samdanci E, Selimoglu E, Iraz M, Miman MC, Haznedaroglu IC. Ankaferd blood stopper is more effective than adrenaline plus lidocaine and gelatin foam in the treatment of epistaxis in rabbits. Curr Ther Res Clin Exp. 2011; 72(5): 185-194. [CrossRef] 
[29] Kazancıoglu HO, Cakır O, Ak G, Zülfikar B. The effectiveness of a new hemostatic agent (ankaferd blood stopper) for the control of bleeding following tooth extraction in hemophilia: A controlled clinical trial. Turk J Haematol. 2013; 30(1): 19-24. [CrossRef]

[30] Cakarer S, Eyupoglu E, Ozcamur GC, Kuseoglu GB, Berberoglu KH, Keskin C. Evaluation of the hemostatic effects of Ankaferd Blood Stopper during dental extractions in patients on antithrombotic therapy. Clin Appl Thromb Hemost. 2013; 19(1): 96-99. [CrossRef]

[31] Bilgili H, Kosar A, Kurt M, Onal IK, Goker H, Captug O, Shorbagi A, Turgut M, Kekilli M, Kurt OK, Kirazli S, Aksu S, Haznedaroglu IC. Hemostatic effects of Ankaferd in a swine bleeding model. Med Princ Pract. 2009; 18(3): 165-169. [CrossRef]

[32] Kosar A, Cipil HS, Kaya A, Uz B, Haznedaroglu IC, Goker H, Ozdemir O, Ercetin S, Kirazli S, Firat HC. The efficacy of Ankaferd Blood Stopper in antithrombotic drug induced primary and secondary hemostatic abnormalities of a rat bleeding model. Blood Coagul Fibrinolysis. 2009; 20: 185-190. [CrossRef]

[33] Oner AF, Doğan M, Kaya A, Sal E, Bektaş MS, Yesilmen O, Ayhan H, Acikgoz M. New coagulant agent (ankaferd blood stopper) for open hemorrhages in hemophilia with inhibitor. Clin Appl Thromb Hemost. 2010; 16(6): $705-707$. [CrossRef]

[34] Zulfikar OB, Emiroglu HH, Kebudi R. Nasogastric application of topical Ankaferd Blood Stopper for bleeding from primary esophageal adenocarcinoma in a child with disseminated intravascular coagulation. Dig Liver Dis. 2011; 43(3): 247-248. [CrossRef]

[35] Tek M, Akkas I, Toptas O, Ozan F, Sener I, Bereket C. Effects of the topical hemostatic agent Ankaferd Blood Stopper on the incidence of alveolar osteitis after surgical removal of an impacted mandibular third molar. Niger J Clin Pract. 2014; 17(1): 75-80. [CrossRef]

[36] Pellati D , Fiore C , Armanini D , et al. In vitro effect of glycyrrhetinic acid on the growth of clinical isolates of Candida albicans. Phytother Res. 2009; 23: 572-574. [CrossRef]

[37] Motsei ML, Lindsey KL, van Staden J , Jäger AK. Screening of traditionally used South African plants for antifungal activity against Candida albicans. J Ethnopharmacol. 2003; 86: 235-241. [CrossRef]

[38] Arslan S, Ertaş H, Zorba YO. Influence of Ankaferd Blood Stopper on shear bond strength of bonding systems. Dent Mater J. 2012; 31(2): 226-31. [CrossRef]

[39] Simsek HO, Teuzeum MS, Baykul T, Geurer IE, Bassorgun CI. Experimental investigation of the effects of a blood stopper agent (Ankaferd Blood Stopper) on bone surfaces. Turk J Haematol. 2013; 30(3): 177-183. [CrossRef]

[40] Trakyali G, Oztoprak MO. Plant extract ankaferd blood stopper effect on bond strength. Angle Orthod. 2010; 80(3): 570-574. [CrossRef]

[41] Ozmen B, Bayrak S. Comparative evaluation of ankaferd blood stopper, ferric sulfate, and formocresol as pulpotomy agent in primary teeth: A clinical study. Niger J Clin Pract. 2017; 20(7): 832-838. [CrossRef]

[42] Odabaş ME, Çinar C, Tulunoğlu O, Işik B. A new haemostatic agent's effect on the success of calcium hydroxide pulpotomy in primary molars. Pediatr Dent. 2011; 33(7): 529-534.

[43] Yaman E, Georken F, Pinar EA, Sepet E, Aytepe Z. Effects of folk medicinal plant extract Ankaferd Blood Stopper in vital primary molar pulpotomy. Eur Arch Paediatr Dent. 2012; 13: 197-202. [CrossRef]

[44] Koyuturk AE, Tunç ES, Bayrak S, Ayas B, Ozmen B, Korkmaz A. Histological evaluation of Ankaferd blood stopper, ferric sulfate and formocresol as pulpotomy agents in rat molars. J Pediatr Dent. 2013; 1(2): 32-36.

[45] Sheela ML, Ramakrishna MK, Salimath BP. Angiogenic and proliferative effects of the cytokine VEGF in Ehrlich ascites tumor cells is inhibited by Glycyrrhiza glabra. Int Immunopharmacol. 2006; 6(3): 494-498. [CrossRef]

[46] Karabıyık A, Yılmaz E, Gülec S, Haznedaroglu I, Akar N. The dual diverse dynamic reversible effects of Ankaferd Blood Stopper on EPCR and PAI-1 inside vascular endothelial cells with and without LPS challenge. Turk J Hematol. 2012; 29: 361-366. [CrossRef]

[47] Ciftci S, Keskin F, Keceli Ozcan S, Erdem MA, Cankaya B, Bingol R, Kasapoglu C. In Vitro Antifungal Activity of Ankaferd Blood Stopper against Candida albicans. Curr Ther Res Clin Exp. 2011; 72(3): 120-126. [CrossRef]

[48] Lee SJ, Umano K, Shibamoto T. Identification of volatile components in basil (Ocimum basilicum L.) and thyme leaves (Thymus vulgaris L.) and their antioxidant properties. Food Chem. 2007; 91(1): 131-137. [CrossRef]

[49] Fatima A, Gupta VK, Luqman S, Negi AS, Kumar JK, Shanker K, Saikia D, Srivastava S, Darokar MP, Khanuja SP.. Antifungal activity of Glycyrrhiza glabra extracts and its active constituent glabridin. Phytother Res. 2009; 23(8): 1190-1193. [CrossRef] 
[50] Bulut E, Baş B, Altunkaynak BZ, Bekçioğlu B, Erdem Koç G, Gönülol E, Önger ME, Kaplan S. Efficacy of Ankaferd Blood Stopper on bone healing in diabetic rats: a stereological and histopathological study. Biotech Histochem. 2014; 89(7): 535-543. [CrossRef]

[51] Pamuk F, Cetinkaya BO, Keles GC, Balli U, Koyuncuoglu CZ, Cintan S, Kantarci A. Ankaferd blood stopper enhances healing after osseous grafting in patients with intrabony periodontal defects. J Periodont Res. 2016; 51: 540-547. [CrossRef]

[52] Coban YK, Ozerol E, Tanber K, Erbatur S, Aytekin AH, Firat C. Hemeostatic efficacy of Ankaferd after excision of full thickness burns: a comparative experimental study in rats. Surgical Science 2011; 2(1):16-21. [CrossRef]

[53] Isler SC, Demircan S, Cakarer S, Cebi Z, Keskin C, Soluk M. Effects of folk medicinal plant extract Ankaferd Blood Stopper on early bone healing. J Appl Oral Sci. 2010; 18(4): 409-414. [CrossRef]

[54] Göker H, Çetinkaya D, Kılıç E, Haznedaroğlu IC, Kirazlı S, Fırat H. Anti-cancer activity of Ankaferd blood stopper on osteosarcoma (SAOS-2) cell lines in vitro. In: Haznedaroğlu I.C. GH, Özdemir O, Koşar A, Firat H, editors. Ankaferd: Scientific perspectives and basic-clinical data. Naviga Publications İstanbul, Turkey 2008: 109.

[55] Göker H, Kılıc E, Çetinkaya D, Haznedaroğlu IC, Kirazlı S, Fırat H. Anti-cancer activity of Ankaferd on human colon cancer (CACO-2) in vitro. In: Haznedaroğlu IC, Göker H, Özdemir O, Koşar A, Fırat H editors. Ankaferd: Scientific perspectives and basic-clinical Data. Naviga Publications İstanbul, Turkey 2008: 108.

[56] Turk S, Malkan UY, Ghasemi M, Hocaoglu H, Mutlu D, Gunes G, Aksu S, Haznedaroglu IC. Growth inhibitory activity of Ankaferd hemostat on primary melanoma cells and cell lines. SAGE Open Med. 2017; 5: 2050312116689519. [CrossRef]

[57] Akalin I, Okur FV, Haznedaroglu IC, Sayinalp N, Aksu S, Buyukasik Y, Goker H. Acute in vitro effects of ABS (Ankaferd hemostat) on the lymphoid neoplastic cells (B-CLL and RAJI tumor cell lines). UHOD. 2014; 24(4): 253259. [CrossRef]

[58] Mumcuoglu M, Akin DF, Ezer U, Akar N. Ankaferd Blood Stopper induces apoptosis and regulates PAR1 and EPCR expression in human leukemia cells. Egypt J Med Human Gen. 2015; 16(1): 19-27. [CrossRef]

This is an open access article which is publicly available on our journal's website under Institutional Repository at http://dspace.marmara.edu.tr. 